\title{
Rare earth element deposition in pelagic sediment at the Cenomanian-Turonian Boundary, Exmouth Plateau
}

\author{
Gerald R. Dickens and Robert M. Owen \\ Department of Geological Sciences, University of Michigan, Ann Arbor, USA
}

\begin{abstract}
ODP Site 762 (eastern Indian Ocean) includes a section of sediment that spans the Cenomanian-Turonian Boundary (CTB) and was deposited along a continental margin during a period of widespread oceanic $\mathrm{O}_{2}$ deficiency. The rare earth element (REE) content of pre- and post-boundary sediment is similar to that of present-day continental slope material deposited in well-oxygenated seawater, whereas the CTB section is characterized by significantly depleted REE abundances, a bulk Ce anomaly that increases to maximum of 1.0, and a REE pattern that resembles that of present-day fluvial material. We suggest the change in REE patterns reflects release of scavenged REEs upon reductive dissolution of authigenic Fe-Mn oxyhydroxides, such that sediment deposited during the CTB is dominated by the lithogenous REE fraction. These results are consistent with recent models concerning pervasive fractionation of $\mathrm{Mn}$ and $\mathrm{Fe}$ and redirection of $\mathrm{Mn}$ in pelagic CTB waters.
\end{abstract}

\section{Introduction}

Understanding how past global change affected carbon and related geochemical cycles is one of the primary objectives currently facing the ocean sciences. Investigations of the Cenomanian-Turonian Boundary (CTB, $-91.5 \mathrm{Ma}$ ) have become a focal point in this endeavor because this period was characterized by massive deposition of organic carbon in marine environments [e.g., De Graciansky et al., 1984; Arthur et al., 1988]. As evidenced by widespread laminated marine sediment at the CTB, this response of the carbon cycle was related to dysoxic to anoxic conditions in the water column, although the cause and dimensions of the $\mathrm{O}_{2}$ deficiency remain unclear [cf. De Graciansky et al., 1984; Pedersen and Calvert, 1990]. However, the duration of these atypical conditions ( $\sim 0.5$ m.y.) can be constrained in many stratigraphic sequences by various biostratigraphic markers (e.g., the $W$. archeocretacea planktonic foraminifera zone) and/or a positive $\delta^{13} \mathrm{C}$ excursion in bulk carbonate and organic matter [e.g., Arthur et al., 1988].

The CTB also has been identified as a time of widespread Mn enrichment without associated Fe enrichment in shallow marine sediment [e.g., Pratt et al., 1991], and significant Mn depletion within contemporaneous Fe-rich deep marine sediment [e.g., Dickens and Owen, 1993]. Recent workers [e.g., Force and Cannon, 1988; Pratt et al., 1991; Dickens and Owen, 1993] have suggested the above observations are linked according to the following model: (1) burial of organic carbon relates to extensive oceanic $\mathrm{O}_{2}$ deficiency; (2) pelagic $\mathrm{Mn}$

\section{Copyright 1995 by the American Geophysical Union.}

depletion reflects dissolution of $\mathrm{Mn}$ oxyhydroxides within the $\mathrm{O}_{2}$ deficient water and diminished deposition of labile $\mathrm{Mn}$; (3) shallow marine $\mathrm{Mn}$ enrichment represents redirection of dissolved $\mathrm{Mn}^{2+}$ and subsequent precipitation at or near a redoxcline; and, (4) minimal Fe concentrations in shallow marine sediment occur because of deep water sequestering of dissolved Fe into pyrite, Fe-rich clays, or both. The model is independent of cause/effect relationships between organic carbon burial and $\mathrm{O}_{2}$ deficiency; i.e., high organic carbon contents in CTB sediment could reflect either enhanced surficial productivity and drawdown of dissolved $\mathrm{O}_{2}$ or, alternatively, enhanced preservation within $\mathrm{O}_{2}$ deficient water [cf. $D e$ Graciansky et al., 1984; Pedersen and Calvert, 1990].

A key implication of this model is that cycles of certain trace elements also would have been perturbed. In well-oxygenated seawater, rare earth elements (REEs) predominantly are delivered to marine sediment in two different host phases: REEs contained in terrigenous material (i.e., aluminosilicates) and REEs associated (via scavenging) with particulate $\mathrm{Fe}-\mathrm{Mn}$ oxyhydroxides [e.g., Murray et al., 1992]. However, investigations in modern anoxic environments show that reductive dissolution of carrier oxyhydroxides results in the release of scavenged REEs [e.g., De Baar et al., 1988; Sholkovitz et al., 1992]. Thus, if the aforementioned model regarding CTB Mn and Fe cycling is correct, the scavenged component of REEs should be absent and the overall REE pattern should be dominated by terrigenous material in bulk sediment deposited within $\mathrm{O}_{2}$ deficient water. This study tests this hypothesis by examining the REE geochemistry of a well-documented sequence of CTB continental slope sediment.

\section{Sample Description and Methods}

Ocean Drilling Program (ODP) Site 762 (19 $53^{\prime} \mathrm{S}$, $112^{\circ} 15^{\prime} \mathrm{E} ; 1360 \mathrm{~m}$ water depth) is located on the Exmouth Plateau $\sim 350 \mathrm{~km}$ from northwest Australia. The Plateau represents a section of Paleozoic passive continental margin that was rifted and uplifted in the early Mesozoic, and since the Aptian, progressively subsided to present water depths [Haq et al., 1992]. Cretaceous sediment at Site 762 predominantly consists of variable proportions of nannofossil chalk and clay, and was deposited on a southeast margin of the Tethys at $-45^{\circ} \mathrm{S}$ paleolatitude [Haq et al., 1990].

Drilling at Site 762 recovered an apparently complete CTB section. The section roughly spans the $W$. archeocretacea biozone [Wonders, 1992] and can be described as a $7.5 \mathrm{~m}$ depth zone (from 806.5 to 814 meters below seafloor; mbsf) in which lithologic and chemical changes occur. The CTB itself (Figure 1) is located between $810.65-810.88$ mbsf. Sediment within this $23 \mathrm{~cm}$ interval is a laminated dark brown fissile claystone lacking organic carbon (total organic carbon < 0.2\%) and dominated by Fe-rich smectite [Haq et al., 1990; Dickens and Owen, 1993]. Other clays (e.g., illite), quartz, 
feldspar, and clinoptilolite are notably deficient within this interval [Haq et al., 1992; Dickens and Owen, 1993]. A similar $2 \mathrm{~cm}$ interval of dark gray claystone exists downcore (between 811.10-811.12 mbsf). The entire $7.5 \mathrm{~m}$ depth zone is non-bioturbated [Haq et al., 1990].

Twenty samples of Cenomanian and Turonian sediment from Site 762 were used for this study. Individual samples represent $2-3 \mathrm{~cm}$ intervals from cores $762 \mathrm{C}-73 \mathrm{X}-2$ through $762 \mathrm{C}$ 77X-1. All bulk samples were split into two replicates, and portions of each replicate then were analyzed for bulk $\mathrm{Ce}, \mathrm{Eu}$, $\mathrm{La}$, and $\mathrm{Sm}$ concentrations by neutron activation analysis (INAA) according to the procedure outlined in Dickens and

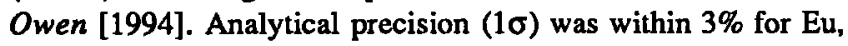
$\mathrm{La}$, and $\mathrm{Sm}$, less than $5 \%$ for $\mathrm{Ce}$, and less than $9 \%$ for $\mathrm{Lu}$ and Yb. Including other random errors (see Dickens and Owen, [1994]), we estimate maximum error $(1 \sigma)$ in reported concentrations to be approximately $5-8 \%$ for $\mathrm{Ce}, \mathrm{Eu}, \mathrm{La}$, and $\mathrm{Sm}$, and less than $13 \%$ for $\mathrm{Lu}$ and $\mathrm{Yb}$. The $\mathrm{Ce}$-anomaly $\left(\mathrm{Ce} / \mathrm{Ce}^{*}\right)$ for all samples is calculated as in Toyoda et al. [1990].

Approximately $30 \mathrm{mg}$ of ground and homogenized sample also were dissolved in $10 \mathrm{ml}$ of $10 \% \mathrm{HCl}$ and analyzed for bulk phosphorous (using the $213.62 \mathrm{~nm}$ line) by inductively coupled plasma spectroscopy (ICP). The purpose of these analyses was to account for the amount of bulk REEs that could be associated with acid-soluable phosphatic phases in sediment at Site 762 . The detection limit $(3 \sigma)$ for $P$ under these analytical conditions is approximately $200 \mu \mathrm{g} / \mathrm{g}$ rock $(\approx 615 \mathrm{ppm}$ $\mathrm{PO}_{4}{ }^{3-}$ ). Concentrations were below this detection limit for all samples analyzed. We therefore assume that maximum acidsoluable $\mathrm{PO}_{4}{ }^{3-}$ concentrations in bulk Cenomanian and Turonian sediment at Site 762 are $\leq 615 \mathrm{ppm}$.

\section{Results and Discussion}

The concentrations (Table 1 and Dickens and Owen [1993]) of all elements (except $\mathrm{Mn}$ ) increase across the CTB (810.76 mbsf). These increases are caused by a decrease in the amount of biogenic carbonate [ $\mathrm{Haq}$ et al., 1990], which serves as a dilutant [e.g., Palmer, 1985]. The significant decrease in Mn across the CTB has been attributed to fewer labile oxyhydroxides [Dickens and Owen, 1993]. Variations in ratios such as $\mathrm{REE} / \mathrm{Al}$ and $\mathrm{Ce} / \mathrm{Ce}$ * (as well as $\mathrm{Mn} / \mathrm{Al}$ ), however, cannot be ascribed to changes in carbonate abundance.

The depth profile of $\mathrm{Sm} / \mathrm{Al}$ (Figure 1) is characterized by relatively low values in sediment deposited prior to the CTB, a general depletion at the CTB, and higher values in sediment deposited after the CTB. In contrast, the $\mathrm{Ce} / \mathrm{Ce}^{*}$ profile (Figure 1) exhibits relatively high values in sediment deposited prior to the CTB, a clear and significant increase (to 0.98 ) at the CTB, and lower values in sediment deposited after the CTB. The intercorrelation $(r>0.84)$ between $\mathrm{La}, \mathrm{Sm}, \mathrm{Eu}$, $\mathbf{Y b}$, and $\mathrm{Lu}$ indicates that Al normalized depth profiles for REEs other than Ce are similar to that of $\mathrm{Sm} / \mathrm{Al}$. However, significant fractionation between the REEs (other than Ce) is observed across the CTB: $\mathrm{La}$ is slightly depleted relative to $\mathrm{Sm}$ and $\mathrm{Eu}$; and, $\mathrm{La}, \mathrm{Sm}$, and $\mathrm{Eu}$ are enriched relative to $\mathrm{Yb}$ and $\mathrm{Lu}$. Bulk $\mathrm{La}, \mathrm{Ce}$, and $\mathrm{Sm}$ concentrations at the defined CTB are within the range of analytical precision of those found in NASC [cf. Piper, 1974], and the overall REE pattern (including heavy REE depletion) is similar to that of present-day riverine suspended material [e.g., Goldstein and Jacobsen, 1988].

Variations in $\mathrm{Sm} / \mathrm{Al}$ and $\mathrm{Ce} / \mathrm{Ce}^{*}$ appear to reflect two trends: (1) increasing $\mathrm{REE} / \mathrm{Al}$ and decreasing $\mathrm{Ce} / \mathrm{Ce}{ }^{*}$ upcore;
Table 1. Bulk rare earth element concentrations for Cenomanian and Turonian samples at ODP Site 762

\begin{tabular}{|c|c|c|c|c|c|c|c|}
\hline $\begin{array}{c}\text { Depth, } \\
\text { mbsf }\end{array}$ & $\begin{array}{l}\text { La, } \\
\text { ppm }\end{array}$ & $\begin{array}{l}\text { Ce, } \\
\text { ppm }\end{array}$ & $\begin{array}{l}\text { Sm, } \\
\text { ppm }\end{array}$ & $\begin{array}{l}\text { Eu, } \\
\text { ppm }\end{array}$ & $\begin{array}{l}\text { Yb, } \\
\text { ppm }\end{array}$ & $\begin{array}{l}\text { Lu, } \\
\text { ppm }\end{array}$ & $\mathrm{Ce} / \mathrm{Ce} *$ \\
\hline 80 & 12.4 & 0 & .64 & 0.47 & 1.1 & 0.15 & 0.37 \\
\hline 802.56 & 18.1 & 10 & 3.06 & 0.67 & 1.6 & 0.22 & 0.46 \\
\hline 806.47 & 15.1 & 12 & 2.00 & 0.54 & 1.3 & 0.19 & 0.41 \\
\hline 807.74 & 14.5 & 10 & 1.96 & 0.52 & 1.3 & 0.18 & 0.37 \\
\hline 809.70 & 24.0 & 2 & 0 & 0.98 & & 0.29 & 0.50 \\
\hline 809 & 22 & & & 0.85 & & & 0.50 \\
\hline 81 & 21.7 & & & 0. & & & .58 \\
\hline & 38. & & & & & & 80 \\
\hline 81 & 38. & 76 & & & & & 0.98 \\
\hline 81 & 29.0 & 46 & 50 & 1.07 & 2.3 & 0.32 & 0.81 \\
\hline 11 & 26.0 & 38 & 4.38 & 1.14 & 1.5 & 0.19 & 0.72 \\
\hline 811 & 18.2 & 20 & 2.79 & 0.72 & 1.7 & 0.24 & 0.55 \\
\hline 812.04 & 27.0 & 36 & 4.19 & 1.03 & 2.0 & 0.27 & 0.68 \\
\hline 812.83 & 23.6 & 30 & 3.44 & 0.85 & 1.7 & 0.24 & 0.66 \\
\hline 814.30 & 32.7 & 34 & 5.48 & 1.32 & 2.6 & 0.32 & 0.53 \\
\hline 814.61 & 14.2 & 18 & 2.02 & 0.52 & 1.4 & 0.20 & 0.66 \\
\hline 815.34 & 11.3 & 16 & 1.63 & 0.39 & 1.1 & 0.14 & 0.73 \\
\hline 818.49 & 21.3 & 37 & 3.52 & 0.89 & 2.0 & 0.34 & 0.89 \\
\hline 81 & 15.6 & 30 & 2.70 & 0.76 & 1. & 0.22 & 0.95 \\
\hline 820.57 & 22.1 & 34 & 3.77 & 0.94 & 2.1 & 0.29 & 0.77 \\
\hline
\end{tabular}

Values of $\mathrm{Ce} / \mathrm{Ce}$ * calculated according to Toyoda et al. [1990]; Concentrations of $\mathrm{Al}$ and $\mathrm{Mn}$ discussed in text and presented in Figure 1 are from Dickens and Owen [1993].

and, (2) an excursion in both parameters at or near the CTB. The first order trend is consistent with previous interpretations regarding the late Cretaceous evolution of the Exmouth Plateau. Lithology, mineralogy, and benthic fauna indicate that Site 762 progressively subsided from water depths of $-300 \mathrm{~m}$ at $100 \mathrm{Ma}$ to water depths of $\sim 800 \mathrm{~m}$ at $80 \mathrm{Ma}$, and that this subsidence was accompanied by a gradual change from dominantly terrigenous to pelagic deposition [Haq et al., 1992]. Analyses of sediment deposited along present and past continental margins demonstrate that an increase in REE/Al and decrease in $\mathrm{Ce} / \mathrm{Ce}$ * occurs with increasing distance from the coast and increasing proportions of pelagic (biogenic carbonate) material [e.g., Courtois and Hoffert, 1977; Murray et al., 1991, and refs. therein]. Thus, the late Cretaceous change in depositional environment at Site 762 should give rise to an upcore increase in $\mathrm{REE} / \mathrm{Al}$ and decrease in $\mathrm{Ce} / \mathrm{Ce} *$; i.e., $\mathrm{REE}$ patterns in lowermost samples dominated by terrigenous material (upwards of $50 \%$ clay) and those of uppermost samples dominated by pelagic material ( $>85 \%$ biogenic carbonate). However, subsidence alone does not adequately explain the pronounced excursions in $\mathrm{REE} / \mathrm{Al}$ and $\mathrm{Ce} / \mathrm{Ce}$ * observed at or near the CTB.

On the basis of planktonic foraminifer biozones and the lack of bioturbation, the interval between 806.5 and $814 \mathrm{mbsf}$ at Site 762 was deposited during the CTB and within $\mathrm{O}_{2}$ deficient bottom water. Moreover, this interval at Site 762 does not reflect simple passage of the location (via subsidence) through a stationary oxygen minimum zone (OMZ); other locations on the Exmouth Plateau that existed at significantly different Cretaceous water depths (e.g., Site 763) also display evidence for pronounced and atypical $\mathrm{O}_{2}$ deficiency during the CTB [see Haq et al., 1992; Dickens and Owen, 1993].

Sediment in the above interval is significantly depleted in 


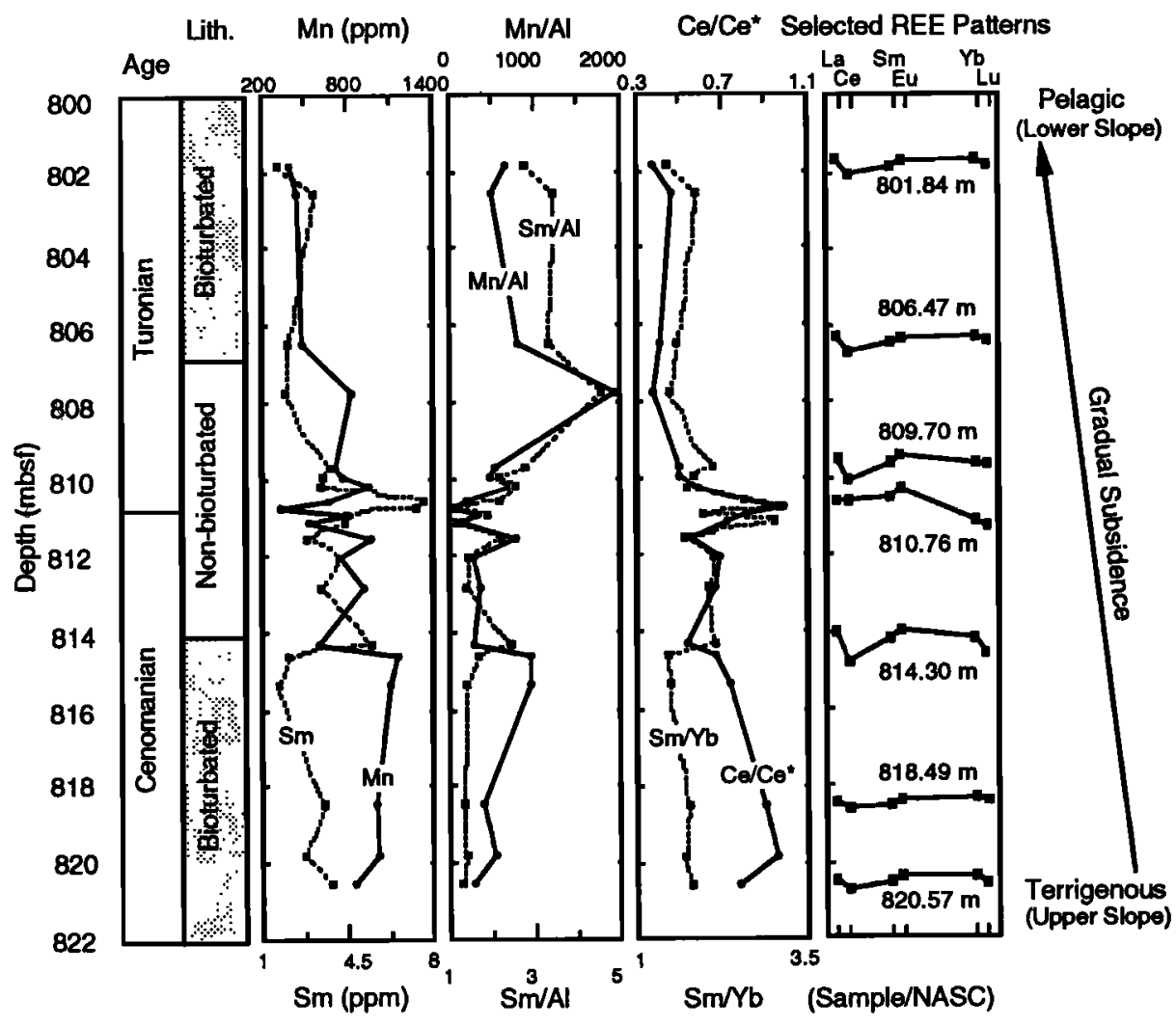

Figure 1. Upcore variations in $\mathrm{Mn}, \mathrm{Sm}, \mathrm{Mn} / \mathrm{Al}, \mathrm{Sm} / \mathrm{Al}, \mathrm{Ce} / \mathrm{Ce}^{*}$ and $\mathrm{Sm} / \mathrm{Yb}$ within Cenomanian and Turonian sediment at Site 762. Note excursions in all parameters within non-bioturbated sediment deposited at or near the Cenomanian-Turonian Boundary (CTB; $810.65-810.88 \mathrm{~m}$ below sea floor). The REE patterns (right) have been normalized to NASC with mean REE $_{N}$ placed at sample depth. Paleodepth reconstructions [Haq et al., 1992] suggest the Exmouth Plateau progressively subsided through time such that the depositional environment at Site 762 gradually changed from upper slope ( $\geq 300 \mathrm{~m}$ water depth) dominated by terrigenous sediment during the early Cenomanian to lower slope ( $\leq 800 \mathrm{~m}$ water depth) dominated by pelagic sediment in the late Turonian.

labile $\mathrm{Mn}$ (see profile of $\mathrm{Mn} / \mathrm{Al}$, Figure 1), and this depletion previously has been ascribed to diminished deposition of oxyhydroxide phases [Dickens and Owen, 1993]. This inference was made on the basis of Mn behavior in modern OMZs [e.g., Johnson et al., 1992]. This interval of depleted Mn broadly coincides with the lack of bioturbation. If extensive oxyhydroxide remobilization had occurred within the sedimentary column, the basal Mn depletion would be below the onset of non-bioturbation, and this is not the case (Figure 1). Note that $\mathrm{Mn}$ concentrations (and the $\mathrm{Mn} / \mathrm{Al}$ ratio) at the defined CTB are not zero, and that the overall $\mathrm{Mn}$ depletion varies in magnitude with respect to depth (and thus, time) between 806.5 and 814 mbsf. Leaching experiments have shown that $\mathrm{Al}$ and "residual" $\mathrm{Mn}$ at the defined CTB is hosted within Ferich smectites; i.e., sediment at $\mathbf{8 1 0 . 7 6} \mathrm{mbsf}$ is devoid of labile Mn [Dickens and Owen, 1993]. Samples immediately above and below the CTB, although deficient in labile $\mathrm{Mn}$, contain oxyhydroxides. One explanation that has been offered at other sites is that dissolved $\mathrm{O}_{2}$ concentrations fluctuated during the CTB.

The interpretation of diminished oxyhydroxide deposition within $\mathrm{O}_{2}$ deficient bottom water is consistent with observed variations in REEs across the CTB at Site 762. A significant non-terrigenous REE contribution to bulk sediment are Fe-Mn oxyhydroxide coatings on biogenic tests [Courtois and Hoffert, 1977; Fleet, 1984; Palmer, 1985; Murray et al.,
1991]. These phases scavenge REEs from surrounding seawater such that, relative to shale, they are greatly enriched in REEs, slightly enriched in La relative to $\mathrm{Sm}$, significantly depleted in $\mathrm{La}$ and $\mathrm{Sm}$ relative to $\mathrm{Yb}$ and $\mathrm{Lu}$, and have a $\mathrm{Ce} / \mathrm{Ce}$ * $\ll 1.0$, with resultant shale-normalized REE patterns broadly paralleling that of seawater [Fleet, 1984; Palmer, 1985; Murray et al., 1991; 1992]. A decrease in the downward flux of sedimentary $\mathrm{Fe}-\mathrm{Mn}$ oxyhydroxides therefore would cause a decrease in $\mathrm{REE} / \mathrm{Al}$, a decrease in $\mathrm{La} / \mathrm{Sm}$, an increase in $\mathrm{La} / \mathrm{Yb}$, and an increase in $\mathrm{Ce} / \mathrm{Ce}$ * within bulk sediment. The similarity between bulk REE concentrations at the CTB and those of present-day fluvial inputs thus can be explained by an absence of a $\mathrm{Fe}-\mathrm{Mn}$ oxyhydroxide component; i.e., deep water sediment deposited at the defined CTB is essentially an Feenriched riverine suspended-load end-member.

Other processes could account for observed chemical changes across the CTB at Site 762: (1) early diagenesis; (2) an increase in the flux of aluminosilicates; and (3) a decrease in the flux of REE-bearing phosphate. The available data do not permit exclusion of the possibility that a sequence of diagenetic reactions resulted in all of the observed trends. This scenario, however, does not negate the inferred link between dysoxic conditions and minimal REE concentrations, but simply extends the basic model to include the possibility that dissolution of host Fe-Mn oxyhydroxides may have occurred within both the sediment column and the water column. 
The latter two possibilities are considered unlikely for the following reasons. An increase in the sedimentary flux of terrigenous material (riverine suspended loads) would produce the same bulk geochemical trends as a decrease in the flux of FeMn oxyhydroxides. This alternative interpretation, however, is inconsistent with paleoceanographic reconstructions of the Cretaceous. The highest Mesozoic-Cenozoic sea level stand occurred during the CTB [Haq et al., 1987], and the depositional position of riverine suspended loads would have shifted landward during this transgression. The terrigenous supply to Site 762, therefore, would be expected to decrease during the CTB. An observed change in predominant mineralogy from quartz and illite in pre-CTB sediment to smectite across the CTB supports this contention [Dickens and Owen, 1993].

Phosphatic phases (e.g., apatite) can become enriched in REEs after deposition, may have a $\mathrm{Ce} / \mathrm{Ce}$ * much less than 1.0 , and can provide a secondary control on bulk REE concentrations in marine sediment [e.g., Grandjean et al., 1987; Toyoda et al., 1990; Murray et al., 1991]. A decrease in phosphate abundance thus might explain certain changes in REE patterns across the CTB. However, chemical data indicate that phosphate is not a significant carrier of REEs at Site 762, and can account for bulk REE concentrations of no more than $14 \%$ in any sample. Pure apatite $\left(-55 \% \mathrm{PO}_{4}{ }^{3-}\right)$ may contain upwards of $200 \mathrm{ppm} \mathrm{Sm}$ after lengthy $\left(>10^{6} \mathrm{yr}\right.$ ) burial [Grandjean et al., 1987], but Cenomanian and Turonian sediment at Site 762 contains a maximum of only $615 \mathrm{ppm} \mathrm{PO}_{4}{ }^{3}$.

Previous investigations have attributed widespread $\mathrm{Mn}$ enrichment without associated $\mathrm{Fe}$ in CTB shallow marine sediment and contemporaneous Mn depletion in Fe-rich deep sea sediment to diminished deposition of labile Fe-Mn oxyhydroxides within deep sea environments because of extensive $\mathrm{O}_{2}$ deficiency [e.g. Force and Cannon, 1988; Pratt et al., 1991]. One implication of this model is that sedimentary fluxes of trace elements (e.g., the REEs) that are scavenged by Fe-Mn oxyhydroxides under oxic conditions also must decrease within the confines of CTB $\mathrm{O}_{2}$ deficiency. The pronounced changes in REE deposition during the CTB at Site 762 can be explained by release of scavenged REEs upon reductive dissolution of $\mathrm{Fe}-\mathrm{Mn}$ oxyhydroxides. The results presented here, therefore, are consistent with and support the CTB Fe$\mathrm{Mn}$ redistribution model. It is important to stress that REE variations across the CTB at Site 762 are inferred to be a "passive" response to changes in oxyhydroxide deposition; i.e., the data do not suggest that variations in REEs (and $\mathrm{Ce} / \mathrm{Ce}$ ) can be used as primary and direct evidence for changes in dissolved $\mathrm{O}_{2}$ [cf. German and Elderfield, 1990].

Acknowledgments. Funding for G. Dickens was provided by a DOE Graduate Fellowship for Global Change administered by ORISE. This manuscript was improved significantly by comments of $R$. Murray and several anonymous reviewers.

\section{References}

Arthur, M.A., W.E. Dean, and L.M. Pratt, Geochemical and climatic effects of increased marine organic carbon burial at the Cenomanian/Turonian boundary, Nature, 335, 714-717, 1988.

Courtois, C. and M. Hoffert, Distribution des terres rares dans les sediments superficiels du Pacifique sud-est, Bull. Soc. Geol. Fr., 19, 1245-1251, 1977.

De Baar, H.J.W., C.R. German, H. Elderfield, and P. Van Gaans, Rare earth element distributions in anoxic waters of the Cariaco Trench, Geochim. Cosmochim. Acta, 52, 1203-1219, 1988.
De Graciansky, P.C., G. DeRoo, J.P. Herbin, L. Montadert, C. Muller, A. Schaaf, and J. Sigal, Ocean-wide stagnation episode in the late Cretaceous, Nature, 308, 346-349, 1984.

Dickens, G.R., and R.M. Owen, Global change and manganese deposition at the Cenomanian-Turonian Boundary, Mar. Georesources Geotech., 11, 27-43, 1993.

Dickens, G.R., and R.M. Owen, Chinook Trough rifting and hydrothermal deposition at Sites 885/886, Proc. Ocean Drill. Program Sci. Results, 145, in press, 1994.

Fleet, A.J., Aqueous and sedimentary geochemistry of the rare earth elements, in Rare Earth Element Geochemistry, Chapter 10, edited P. Henderson, pp. 343-373, Elsevier, 1984.

Force, E.R., and W.F. Cannon, Depositional model for shallow-marine manganese deposits around black shale basins, Econ. Geol., 83, 93$117,1988$.

German, C.R., and H. Elderfield, Application of the Ce anomaly as a paleoredox indicator: the ground rules, Paleoceanography, 5, 823833, 1990.

Grandjean, P., H. Cappetta, A. Michard, and F. Albarede, The assessment of REE patterns and ${ }^{143} \mathrm{Nd} /{ }^{144} \mathrm{Nd}$ ratio in fish remains, Earth Planet. Sci. Lett., 84, 181-196, 1987.

Goldstein, S.J., and S.B. Jacobsen, Rare earth elements in river waters, Earth Planet. Sci. Lett., 89, 35-47, 1988.

Haq, B.U., R.L. Boyd, N.F. Exon, and U. Von Rad, Evolution of the central Exmouth Plateau: a post-drilling perspective,.Proc. Ocean Drill. Prograim Sci. Results, 122, 801-816, 1992.

Haq, B.U., et al., Proc. Ocean Drill. Program Init. Rep., 122, 1990.

Haq, B.U., J. Hardenbol, and P.R. Vail, Chronology of fluctuating sea levels since the Triassic, Science, 235, 1156-1166, 1987.

Johnson K.S., W.M. Berelson, K.H. Coale, T.L. Coley, V.A. Elrod, W.R. Fairey, H.D. Iams, T.E. Kilgore, J.L. Nowicki, Manganese flux from continental margin sediments in a transect through the oxygen minimum, Science, 257, 1242-1245, 1992.

Murray, R.W., M.R. Buchholtz Ten Brink, D.C. Gerlach, G.P. Russ III, and D.L. Jones, Rare earth, major, and trace elements in chert from the Franciscan Complex and Monterey Group, California: assessing REE sources to fine-grained marine sediments, Geochim. Cosmochim. Acta, 55, 1875-1895, 1991.

Murray, R.W., M.R. Buchholtz Ten Brink, D.C. Gerlach, G.P. Russ III, and D.L. Jones, Interoceanic variation in the rare earth, and trace element depositional chemistry of chert: Perspectives gained from the DSDP and ODP record, Geochim. Cosmochim. Acta, 56, 18971913, 1992.

Palmer, M.R., Rare earth elements in foraminifera tests, Earth Planet. Sci. Lett., 73, 285-298, 1985.

Piper, D.Z., Rare earth elements in the sedimentary cycle, a summary, Chem. Geol., 14, 285-304, 1974.

Pedersen, T.F., and S.E. Calvert, Anoxia vs. productivity: what controls the formation of organic-carbon-rich sediments and sedimentary rocks, A.A.P.G. Bull., 74, 454-466, 1990.

Pratt, L.M., E.R. Force, B. Pomerol, Coupled manganese and carbonisotopic events in marine carbonates at the Cenomanian-Turonian Boundary, J. Sed. Pet., 61, 370-383, 1991.

Sholkovitz, E.R., T.J. Shaw, and D.L. Schneider, The geochemistry of rare earth elements in the seasonally anoxic water column and porewaters of Chesapeake Bay, Geochim. Cosmochim. Acta, 56, 1093-1103, 1992.

Toyoda K., Y. Nakamura, and A. Masuda, Rare earth elements of Pacific pelagic sediments, Geochim. Cosmochim. Acta, 54, 1093$1103,1990$.

Wonders, A.A.H., Cretaceous planktonic foraminiferal biostratigraphy, Leg 122, Exmouth Plateau, Australia, Proc. Ocean Drill. Program, Sci. Results, 122, 587-599, 1992.

G.R. Dickens, R.M. Owen, Department of Geological Sciences, University of Michigan, Ann Arbor, MI 48109-1063.

(Recieved May, 17, 1994; Revised September, 22, 1994; Accepted

November, 7, 1994) 